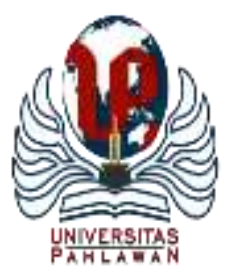

Edukatif : Jurnal Ilmu Pendidikan Volume 4 Nomor 1 Tahun 2022 Halm 308 - 315

EDUKATIF: JURNAL ILMU PENDIDIKAN

Research \& Learning in Education

https://edukatif.org/index.php/edukatif/index

\title{
Hubungan antara Mindful Parenting dan Bimbingan Orang Tua Terhadap Perilaku Moral Siswa Sekolah Dasar Selama Pembelajaran Daring
}

\author{
Zainul Arifin', Yulia Eka Yanti ${ }^{2 凶}$ \\ Pendidikan Guru Sekolah Dasar, Universitas Islam Raden Rahmat Malang, Indonesia ${ }^{1,2}$ \\ E-mail : zainularifinqr22@ gmail.com ${ }^{1}$, yuliaekay@ gmail.com ${ }^{2}$
}

\begin{abstract}
Abstrak
Tujuan dari penelitian ini adalah mengetahui hubungan antara mindful parenting dan bimbingan orang tua terhadap perilaku moral siswa selama pembelajaran daring di SD Negeri Se-Kecamatan Ngajum. Jenis penelitian yang digunakan adalah non-eksperimen dengan pendekatan kuantitatif. Jumlah sampel yang digunakan dalam penelitian ini sebanyak 260 siswa. Instrumen yang digunakan adalah: wawancara, angket dan dokumentasi. Pengujian hipotesis yang digunakan adalah uji korelasi sederhana dan uji korelasi berganda. Hasil penelitian menunjukkan bahwa terdapat hubungan yang signifikan antara mindful parenting dan bimbingan orang tua dengan perilaku moral siswa. Uji korelasi berganda antara mindful parenting dengan perilaku moral siswa menunjukkan hasil Uji korelasi berganda menunjukkan nilai signifikansi 0,000 yang berarti nilai tersebut lebih kecil dari nilai probabilitas 0,05. Nilai $R$ Square sebesar 0,145 yang berarti kontribusi mindful parenting dan bimbingan orang tua terhadap perilaku moral siswa sebesar $14,5 \%$.
\end{abstract}

Kata Kunci: Mindful parenting, bimbingan orang tua, perilaku moral siswa, pembelajaran daring

\section{Abstract}

The purpose of this study was to determine the relationship between mindful parenting and parental guidance on students' moral behavior during online learning in Elementary School in Ngajum District. The type of research used is non-experimental with a quantitative approach. The number of samples used in this study were 260 students. The instruments used are: interviews, questionnaires and documentation. Hypothesis testing used is simple correlation test and multiple correlation test. The results showed that there was a significant relationship between mindful parenting and parental guidance with students' moral behavior. The multiple correlation test between mindful parenting and students' moral behavior shows the results of the multiple correlation test showing a significance value of 0.000, which means that the value is smaller than the probability value of 0.05. The value of $R$ Square is 0.145 , which means that the contribution of mindful parenting and parental guidance to students' moral behavior is $14.5 \%$.

Keywords: Mindful Parenting, Parental Guidance, Student Moral Behavior and Online Learning

Copyright (c) 2022 Zainul Arifin, Yulia Eka Yanti

$\triangle$ Corresponding author

Email : yuliaekay@gmail.com

DOI : https://doi.org/10.31004/edukatif.v4i1.1423

ISSN 2656-8063 (Media Cetak)

ISSN 2656-8071 (Media Online) 


\section{PENDAHULUAN}

Pada awal 2020 dunia dikejutkan oleh wabah virus bernama Corona Virus Disease 2019 atau yang biasa dikenal dengan Covid-19. Merespon hal tersebut pemerintah Republik Indonesia menetapkan bahwa Covid-19 sebagai bencana nasional. Kosekuensi dari wabah dan kebijakan tersebut adalah Pembatasan Sosial Berskala Besar (PSBB), hal ini sesuai dengan PP nomor 21 Tahun 2020 tentang Pembatasan Sosial Berskala Besar Dalam Rangka Percepatan Corona Virus Disease 2019 (Covid-19). Berdasarkan PP Nomor 21 pasal 4 Ayat 1 menjelaskan bahwa Pembatasan Sosial Berskala Besar paling sedikit meliputi (1) Peliburan sekolah dan tempat kerja; (2) Pembatasan keagamaan; (3) Pembatasan kegitaan di tempat atau fasilitas umum. Dampak yang ditimbulkan setelah diterbitkannya PP tersebut banyak kegiatan yang harus dilakukan dari rumah atau biasa dikenal dengan Work From Home (WFH) tak terkecuali pendidikan. Pendidikan yang biasanya dilaksanakan dengan tatap muka, kali ini harus dilaksanakan dengan daring. Media yang digunakan dalam pembelajaran daring menyesuaikan dengan karakteristik dan kondisi yang ada di kelas. Aplikasi yang banyak digunakan adalah adalah Whatsapp, Zoom, Gmeet, dan Classroom. Penggunaan aplikasi ini harus dalam pengawasan orang tua.

Pembelajaran daring melibatkan orang tua lebih dari biasanya. Peran guru sebagai pengajar, pendidik, pembimbing dan pemberi motivasi dalam pembelajaran daring adalah peran orang tua. Namun berdasarkan survei yang dilakukan oleh KPAI (2021) dengan pertanyaan "mendampingi anak saat belajar selama pandemi Covid-19?" didapatkan hasil bahwa ibu yang selalu mendampingi anak ketika belajar sebesar $20 \%$, ayah hanya $10,8 \%$. Pendampingan orang tua pada kategori sering sebesar $32,6 \%$ untuk ibu dan $18,9 \%$ untuk ayah. Berhasil atau tidaknya tergantung proses belajar yang dialami siswa ketika berada di lingkungan keluarga dalam mendampingi anak. Sejatinya orang tua adalah penanggung jawab semua pendidikan anak, hanya peran tersebut dilimpahkan kepada guru. Orang tua hendaknya memberikan perhatian, memperlakukan dengan baik, berbicara dari hati ke hati, mendengar dengan hati dan memberikan welas asih sebagai bentuk pendidikan dan perhatian anak kepada orang tua. Hal tersebut hendaknya dilakukan secara terus-menerus sehingga anak mendapatkan pengasuhan yang ideal dari orang tua. Ketika orang tua menerapkan prinsip-prinsip tersebut maka orang tua menerapkan mindful parenting. Mindful parenting adalah bentuk kesadaran orang tua dalam mengasuh anaknya, memberikan perhatian, tidak memberikan penilaian negatif pada semua hal yang dilakukan oleh anaknya (Duncan, Coatsworth and Greenberg, 2009). Mindful parenting diberikan orang tua kepada anak sebagai bentuk perhatian dan kepedulian orang tua agar berkembang sesuai potensi dan nilai kehidupan. Sehingga anak mampu mencapai apa yang menjadi tujuan anak dengan cara yang baik dan benar.

Sochib (2000) menambahkan bahwa peran orang tua dalam membesarkan anak tidak hanya penting dalam melindungi anak dari berbagai hal negatif, tetapi juga berperan dalam membentuk karakter dan kepribadian anak agar menjadi makhluk yang selalu patuh memenuhi tugasnya. Orang tua punya cara masingmasing dalam mengasuh anak, ada orang tua yang memberikan kebebasan kepada anak. Hal ini tercermin dari bagaimana orang tua membebaskan anak untuk mengembangkan bakat dan minat yang dimiliki oleh anak. Orang tua juga memberikan apresiasi anak dalam proses pengembangan bakat tersebut, perlakuan seperti ini menjadikan anak nyaman untuk mengembangkan bakat yang dipilih. Orang tua berkomunikasi dengan anak dari hati ke hati tentang kehidupan anak, sehingga orang tua dapat mengetahui persoalan anak dan dapat memotivasi anak sesuai dengan permasalahan yang dihadapi, termasuk permasalahan dalam pendidikan (Lagiana, 2017).

Orang tua memiliki peran yang sama pentingnya sebagai guru dan siswa. Tugas guru sebagai pendidik tidak hanya mengajar tetapi juga membimbing, mengarahkan, memotivasi dan mengevaluasi proses pembelajaran yang harus dilakukan orang tua dengan baik saat pembelajaran online (Aji, 2018). Spesifikasi yang dimiliki oleh guru harus dimiliki oleh orang tua. Orang tua harus mampu untuk memberikan pemahaman kepada anak, memberikan bimbingan dan memberikan semangat kepada anak. Idealnya ketika melaksanakan 
pembelajaran daring orang tua selalu mendapingi anak agar tidak kebingungan ketika menerima materi dari guru. Namun tidak semua orang tua dapat mendampingi anaknya saat belajar online karena sebagian orang tua bekerja (Yunitasari and Hanifah, 2020).

Tidak jarang siswa lamban belajar mengalami kesulitan untuk menguasai keterampilan yang bersifat akademis dan kesulitan dalam menyelesaikan masalah yang bersifat kompleks (Julkifli, 2019). Orang tua harus membantu untuk memberikan penjelasan sehingga siswa paham dan mampu menyelesaikan tugas yang diberikan oleh guru. Ketika anak mengalami kesulitan mengerjakan tugas biasanya siswa akan menjadi cepat lelah, jenuh dan frustasi, dalam situasi seperti ini peran orang tua sebagai pengganti guru harus memberikan penjelasan dan motivasi agar siswa menjadi nyaman, paham dan kembali bersemangat untuk menyelesaikan tugas yang diberikan guru.

Faktor pola asuh orang tua menentukan kenyamanan anak dalam interaksi di antara keduannya. Usia orang tua, keterlibatan ayah, pendidikan orang tua, pengalaman mengasuh anak sebelumnya, kondisi psikis orang tua saat itu dan hubungan suami istri menjadi faktor pola asuh orang tua pada anak. Semakin matang orang tua dalam aspek-aspek di atas maka orang tua bisa menentukan apa yang harus dilakukan ketika anak menunjukkan gejala-gejala dalam belajar atau kehidupan sehari-hari. Namun berdasarkan survei yang dilakukan oleh KPAI (2015) Hanya 27,9\% ayah dan 36,6\% ibu yang mencari informasi tentang kualitas menjadi orang tua sebelum menikah. Juga dalam survei yang sama, KPAI juga menemukan dalam surveinya bahwa hingga $66,4 \%$ ayah dan $71 \%$ ibu meniru pendidikan orang tua sebelumnya. Observasi awal yang dilakukan di SD Negeri 1 Kesamben didapatkan bahwa orang tua ketika pembelajaran daring tidak terlalu memperhatikan anak. hal ini terindikasi dengan minimnya feedback dari orang tua ketika sesi sharing dengan guru. Selain itu, ketika mengerjakan tugas sekolah ditemukan beberapa orang tua yang tidak sabar ketika membimbing anak, hal ini terindikasi dengan adanya siswa yang tidak mengerjakan tugas atau mengerjakan tugas namun yang mengerjakan adalah orang tua.

Faktor penting dalam pembelajaran daring selain pendampingan dalam hal belajar adalah fasilitas yang diberikan orang tua. Ada beberapa hal yang mempengaruhi pembelajaran daring, diantaranya perangkat yang mendukung dan koneksi yang stabil. Apabila fasilitas yang diberikan orang tua memadai maka anak menjadi lebih nyaman saat melaksanakan pembelajaran, sehingga hasil pembelajaran akan lebih maksimal. Namun, banyak orang tua yang belum mampu untuk memberikan fasilitas yang memadai untuk pembelajaran daring. Hal ini disebabkan karena kondisi ekonomi orang tua yang belum mampu dan ada orang tua yang belum sadar pentingnya pemberian fasilitas untuk pembelajaran anak. Selain itu, koneksi atau dalam hal ini bisa disebut dengan kouta internet yang membutuhkan banyak kouta masih belum bisa dipenuhi seluruhnya orang tua. Adanya bantuan kouta/pulsa dari pemerintah cukup membantu meskipun belum sepenuhnya terpenuhi kebutuhan seluruhnya.

Menurut penelitian yang dilakukan oleh Aini (2011) Adapun beberapa kasus ditemukan bahwa siswa belum berhasil dalam proses belajarnya. Banyak siswa yang belum menunjukkan perubahan perilaku moral kearah yang lebih baik setelah menerima pelajaran dari guru. Belum maksimalnya pelajaran yang diberikan guru yang ditransfer menjadi perubahan perilaku. Setiap siswa pasti memiliki cara tersendiri dalam menyerap dan menerima penjelasan guru. (De Porter, 1999). Selain itu, pola asuh orang tua menjadi salah satu faktor yang mempengaruhi perilaku moral siswa dalam kehidupan sehari-hari.

Moral mencakup sifat-sifat yang unik pada manusia dan tidak terdapat pada makhluk hidup lainnya. Manusia dapat mencapai moralitas dengan berinteraksi dengan lingkungan atau dengan orang lain. Lingkungan yang dimaksud meliputi lingkungan rumah, sekolah dan masyarakat. Sejak lahir, orang tidak memiliki moral, seperti keluarga, anak-anak dididik menjadi badan hukum (Risdiany and Lestari, 2021). Menurut Mini (2010) Perilaku moral adalah perilaku seseorang dalam hubungannya dengan orang lain yang mengacu pada seperangkat aturan, kebiasaan, dan prinsip tertentu yang berdampak pada kesejahteraan manusia. Selanjutnya Sarkawi (2008) juga mengatakan perilaku moral merupakan sesuatu yang tersembunyi 
311 Hubungan antara Mindful Parenting dan Bimbingan Orang Tua Terhadap Perilaku Moral Siswa Sekolah Dasar Selama Pembelajaran Daring - Zainul Arifin, Yulia Eka Yanti

DOI: https://doi.org/10.31004/edukatif.v4i1.1423

dalam pikiran seseorang karena tersimpan dalam cara berpikirnya. Tingkah laku seseorang sehari-hari merupakan cerminan dari pikiran yang tersimpan di dalam dirinya.

Hal tersebut diperkuat dengan adanya penelitian Lagiana (2017) yang menyatakan bahwa bimbingan orang tua dan pola asuh orang tua berpengaruh positif terhadap perilaku belajar siswa kelas IV dan V di SD Negeri 2 Grogol Sawoo Ponorogo. Penelitian yang dilakukan (Alfianti, 2018) diperoleh hasil bahwa ada hubungan antara mindful parenting dengan stress pengasuhan ibu yang memiliki anak retardasi mental di SLB-C Kabupaten Jember. Penelitian ini menunjukkan bahwa ibu yang mempraktekkan mindful parenting dalam mengasuh anak dengan retardasi mental akan terhindar dari kondisi stress. Menurut penelitian Fadhilah (2019) diperoleh hasil bahwa ada hubungan antara pola asuh orang tua dengan perilaku moral anak kelompok B1 di TK ABA II Kecamatan Sumbersari Kabupaten Jember.

Berdasarkan hasil temuan dilapangan dan latar belakang tersebut, maka tujuan dari penelitian ini yaitu ingin mengetahui hubungan antara mindful parenting dan bimbingan orang tua terhadap perilaku moral siswa sekolah dasar selama pembelajaran daring.

\section{METODE PENELITIAN}

Pendekatan yang digunakan pada penelitian ini adalah kuantitatif dengan non-eksperimental. Penelitian ini menggunakan metode deskriptif dan jenis penelitian korelasional. Populasi .dalam penelitian adalah seluruh siswa Sekolah Dasar di Kecamatan Ngajum. Teknik sampling yang digunakan adalah cluster sampling dengan hasil 5 desa, setiap desa diambil 1 sekolah dasar untuk dijadikan tempat penelitian. Besar sampel yang digunakan adalah 260 siswa. Uji hipotesis menggunakan uji korelasi sederhana dengan product moment dan uji korelasi berganda dengan Anova. Teknik analisis yang digunakan adalah analisis deskriptif.

\section{HASIL DAN PEMBAHASAN PENELITIAN}

\section{Hubungan Mindful Parenting (X1) Terhadap Perilaku Moral Siswa (Y)}

Berdasarkan uji korelasi sederhana antara mindful parenting dengan perilaku moral siswa diperoleh nilai sig. ( 2 tailed) adalah 0,000 dan nilai correlation sebesar 0,281 . Karena nilai sig. ( 2 tailed) bernilai 0,000 kurang dari 0,05, maka dapat disimpulkan bahwa terdapat hubungan yang linier dan berkorelasi rendah antara mindful parenting (X1) dengan perilaku moral siswa (Y). Hasil penelitian ini diperkuat dengan wawancara dengan narasumber salah satu guru dari SD Negeri 4 Ngajum. Penyebab rendahnya korelasi adalah kurang bijaksana orang tua dalam menyelesaikan tugas anak. Ketika anak mengalami kesulitan dalam mengerjakan tugas orang tua tidak memberikan bimbingan kepada anak agar bisa menyelesaikan masalah tersebut, namun justru orang tua yang mengerjakan tugas sekolah tersebut.

Berdasarkan skor rata-rata indikator, salah satu indikator yang mempunyai rata-rata tinggi yaitu mendengarkan dengan penuh perhatian. Jika dilihat dari sudut pandang mindful parenting, menyatakan bahwa masalah yang timbul pada anak seringkali disebabkan oleh orang tua saat berkomunikasi dengan anak. Komunikasi yang efektif dapat menciptakan pola asuh yang positif. Komunikasi pola asuh yang efektif dapat ditempuh dengan menerapkan aspek-aspek mindful parenting, sehingga anak dapat memiliki pengalaman yang baik dari apa yang dilakukan oleh orang tua (Sofyan, 2019).

Perkembangan moral juga bisa dilakukan dengan dialog tentang nilai-nilai antara orang tua dan anak. Peningkatan tahap perkembangan pemahaman moral anak dimungkinkan karena dalam situasi itu terjadi transfer peran, yaitu pertukaran pandangan antara anak dan orang tua. (Zainuddin, 2005). Komunikasi interpersonal yang baik juga akan menghasilkan umpan balik yang baik. Komunikasi interpersonal diperlukan untuk mengatur perilaku sosial antar manusia, karena melakukan komunikasi interpersonal yang baik akan berdampak langsung pada struktur seseorang dalam kehidupannya (Cangara, 2006). 
Komunikasi interpersonal dalam keluarga sangat penting karena dengan adanya komunikasi interpersonal antar anggota keluarga akan tercipta hubungan yang harmonis dan dapat diketahui salah satu apa yang diinginkan dan tidak diinginkan oleh anggota keluarga. Komunikasi interpersonal dalam keluarga berarti hubungan timbal balik antara anggota keluarga untuk berbagi hal dan makna yang berbeda dalam keluarga. Tujuan komunikasi interpersonal dalam keluarga adalah untuk mempersepsikan dunia luar, mengubah sikap dan perilaku. Jadi, dengan menerapkan komunikasi interpersonal yang baik, diharapkan perkembangan pemahaman moral akan berjalan dengan baik pada seorang remaja. (Widjaya, 2000).

Faktor-faktor yang mempengaruhi keefektivitasan komunikasi interpersonal menurut Widjaja (2000) yaitu keterbukaan antar anggota keluarga, sehigga ketika berkomunikasi orang lain akan mengetahui pendapat, pikiran dan gagasan. Begitu pula sebaliknya, ketika kita memberikan tanggapan dari komunikasi seseorang dapat memberikan tanggapan dengan jujur dan terus terang. Namun, keterbukaan tidak akan efektif jika tidak ada perilaku sportif dari seseorang. Artinya seseorang dalam menghadapi masalah tidak berperilaku defensif (bertahan).

Selain keterbukaan dalam komunikasi, penerimaan diri penting bagi anak. Hal ini terkonfirmasi dari penelitian yang menunjukkan hasil terdapat hubungan antara penerimaan diri dengan moral anak (Herminingsih, 2013). Orang tua harus sadar melihat anak seperti itu adanya, harus menerima anak dengan atributnya sendiri. Menerima bahwa orang tua bukanlah anak semasa kecil. Menerima bahwa anak masa kini bukanlah orang tua ketika dulu berstatus anak-anak. Sehingga anak dan orang tua akan berkembang menyesuaikan dengan moral, kerilmuan masa kini dan dapat menyesuaikan emosi dengan norma-norma di lingkungannya.

Emosi memainkan peran yang sangat penting dalam perkembangan anak, baik pada masa kanak-kanak awal maupun perkembangan selanjutnya, karena emosi mempengaruhi perilaku anak. Woolfson mengatakan anak-anak memiliki kebutuhan emosional, seperti ingin dicintai, dihargai, aman, merasa kompeten dan mengoptimalkan keterampilan mereka (Nurmalitasari, 2015). Goleman (2005) Kecerdasan emosional adalah kemampuan mengenali emosi diri sendiri dan orang lain, kemampuan memotivasi diri sendiri, dan kemampuan mengelola emosi dengan baik pada diri sendiri maupun dalam hubungan dengan orang lain agar perilaku anak sesuai dengan standar yang ada di lingkungannya.

Kemampuan tersebut tidak terlepas dari kemampuan orang tua atau keluarga yang merupakan sekolah pertama bagi setiap anak. Ketika di keluarga, anak memperoleh banyak pembelajaran yang sangat berarti untuk kehidupan. Apabila diibaratkan keluarga adalah akar yang menentukan akan menjadi apa dan bagaimana seorang individu anak tersebut. Bila keluarga membimbing dengan cara yang baik dan menjalankan fungsi keluarga, maka individu anak yang dilahirkan mempunyai moral yang baik sehingga membentuk sumber daya manusia yang berkualitas (Hasyim, 2016).

\section{Hubungan Bimbingan Orang Tua (X2) Terhadap Perilaku Moral Siswa (Y)}

Uji korelasi sederhana antara bimbingan orang tua dengan perilaku moral siswa diperoleh nilai sig. (2 tailed) adalah 0,000 dan nilai correlation sebesar 0,331. Karena nilai sig. ( 2 tailed) bernilai 0,000 kurang dari 0,05, maka dapat disimpulkan bahwa terdapat hubungan yang linier dan berkorelasi rendah antara bimbingan orang tua (X1) dengan perilaku moral siswa (Y). Hasil dari penelitian ini diperkuat dengan wawancara yang dilakukan kepada salah satu guru yang menyatakan bahwa sebagian orang tua adalah petani yang bekerja di sawah atau di kebun. Pekerjaan ini menyebabkan orang tua kurang dalam memperhatikan anak dalam kehidupannya sehari-hari. Tidak jarang orang tua menitipkan anaknya kepada tetangga atau kakak dari anak tersebut, sehingga anak tidak mendapatkan bimbingan dan contoh dari orang tua secara langsung.

Selain itu, hasil penelitian ini juga dikuatkan dengan penelitian yang menyatakan bahwa perubahan tingkah laku anak berkembang sesuai dengan usianya (Fitri and Na imah, 2020). Hal ini membuktikan bahwa moral dan anak tidak dilahirkan secara bersamaan, namun tumbuh dan berkembang selaras dengan kondisi 
313 Hubungan antara Mindful Parenting dan Bimbingan Orang Tua Terhadap Perilaku Moral Siswa Sekolah Dasar Selama Pembelajaran Daring - Zainul Arifin, Yulia Eka Yanti

DOI: https://doi.org/10.31004/edukatif.v4i1.1423

yang lingkungan dan bimbingan dari orang tua maupun pendidik. Secara rinci menurut Yusuf (2011) Orang tua memiliki peran sebagai pembimbing atau guru. Orang tua membantu anak dengan mempersiapkan diri untuk membantu belajar dengan menjelaskan bagian-bagian dari pemahaman anak mereka, membantu mereka mengatur waktu belajar mereka, dan memperbaiki masalah belajar anak dan perilaku siswa yang buruk. Selain itu orang tua berperan sebagai motivator, tauladan bagi anak dan pendamping dalam menyelesaikan masalah yang dihadapi anak.

Orang tua memegang peranan penting dalam membentuk kepribadian anak. Nilai seseorang dalam masyarakat tidak hanya diukur dari kemampuan cerdasnya, tetapi juga oleh kemampuannya bersosialisasi dan keterampilan komunikasinya. Sudah menjadi tugas orang tua untuk menciptakan pribadi yang sukses tidak hanya di bidang keilmuan, tetapi juga di bidang sosial. (Nuraini and Mahmud, 2020). Dalam proses pendidikan, orang tua menghadapi berbagai kendala. Hambatan tersebut bisa berasal dari orang tua, anak atau lingkungan. Perkembangan zaman yang modern menuntut seseorang untuk mampu bersaing, berkat kecanggihan teknologi informasi dan komunikasi. Inilah salah satu kendala yang dihadapi orang tua dalam pendidikan moral dan agama anak-anaknya. Oleh karena itu, orang tua perlu dapat menentukan apa yang terbaik untuk anaknya di tengah dampak perkembangan teknologi yang begitu pesat.

Salah satu hambatan yang dihadapi orang tua adalah pembelajaran daring yang menjadi solusi pembelajaran ditengah pandemi Covid-19. Hal ini terkonfirmasi dari hasil wawancara yang dilakukan kepada salah satu guru di SD Negeri 4 Ngajum yang menyatakan bahwa sebenarnya orang tua peduli dengan pendidikan anaknya namun harus terkendala dengan kesibukan pekerjaan, kesibukan mengurus rumah hingga keterbatasan kemampuan orang tua dalam mendampingi anak terutama dalam pembelajaran daring. Keterbatasan tersebut membuat pembentukan perilaku moral anak terhambat karena semakin berkurangnya contoh teladan anak ketika belajar. Peran teladan ketika pembelajaran di sekolah salah satunya adalah guru.

Faktor yang mempengaruhi kurang lancarnya bimbingan orang tua adalah kurangnya perhatian dari orang tua dalam membimbing belajar anak dengan alasan kesibukan pekerjaan rumah tangga, terbatasnya kemampuan biaya orang tua yang menyebabkan orang tua belum dapat memenuhi seluruh kebutuhan anakanaknya dan perilaku anak yang kurang baik disebabkan karena kurangnya bimbingan belajar orang tua (Habsoh, 2021).

Ketika pembelajaran daring orang tua menjalankan peran sebagai agen pendidik. Namun dalam menjalankan tugas orang tua melakukan berbagai kesalahan. Misalnya terlalu memanjakan anak ketika belajar sehingga anak menjadi tidak terlalu peduli dengan belajarnya bahkan hingga orang tua yang mengerjakan tugas anaknya. Kadang ada orang tua yang kasar atau tidak peduli dengan anak sehingga anak mempunyai watak yang keras dan tidak menghormati orang tua.

\section{Hubungan Mindful Parenting (X1) dan Bimbingan Orang Tua (X2) Terhadap Perilaku Moral Siswa (Y)}

Uji korelasi yang terakhir adalah uji korelasi berganda untuk mencari hubungan antara mindful parenting dan bimbingan orang tua dengan perilaku moral siswa. Hasil dari analisis diketahui bahwa nilai Sig. F Change sebesar 0,000 yang berarti lebih kecil dari 0,05 maka artinya terdapat hubungan mindful parenting (X) dan bimbingan orang tua (Y) dengan perilaku moral siswa..

Selain itu, berdasarkan hasil uji korelasi ganda menunjukkan bahwa kontribusi mindful parenting dan bimbingan orang tua sebesar 0,145 artinya kontribusi mindful parenting dan bimbingan orang tua terhadap perilaku moral sebesar $14,5 \%$ sedangkan $85,5 \%$ perilaku moral siswa dipengaruhi oleh variabel lainnya. Hasil ini sesuai dengan hasil uji korelasi sederhana antara mindful parenting terhadap perilaku moral siswa serta bimbingan orang tua terhadap perilaku moral siswa, kedua uji korelasi sederhana tersebut sama-sama berkorelasi rendah.

Hasil ini sesuai dengan penelitian yang dilakukan oleh Sakti (2015) dengan hasil pola asuh dan bimbingan orang tua mampu membentuk perilaku moral anak yang terwujud dengan kebiasaan dan pola 
314 Hubungan antara Mindful Parenting dan Bimbingan Orang Tua Terhadap Perilaku Moral Siswa Sekolah Dasar Selama Pembelajaran Daring - Zainul Arifin, Yulia Eka Yanti

DOI: https://doi.org/10.31004/edukatif.v4i1.1423

disiplin anak (Awang, 2015). Situasi dan sosial memberikan pengaruh terhadap moralitas anak. situasi yang dimaksud adalah situasi yang ada didekat anak atau lingkungan anak. Kedekatan situasi anak membawa anak berada dalam konteks kehidupan yang didalamnya terdapat norma masyarakat. Sosial mengacu pada keluarga, teman sebaya. Aspek ini berperan memberikan pengalaman dan pengetahuan yang akan diserap oleh anak. Melalui konteks sosial, anak akan belajar (Berns, 2010)

Berdasarkan penjelasan dari hubungan mindful parenting terhadap perilaku moral dan hubungan bimbingan orang tua dan perilaku moral dapat disimpulkan bahwa yang dapat mempengaruhi moral diantaranya pertama, Komunikasi efektif yang dapat membangun pengasuhan positif. Komunikasi efektif dalam pengasuhan dapat diupayakan dengan penerapan dimensi-dimensi mindful parenting oleh orang tua. Sehingga anak dapat memiliki pengalaman yang baik dari apa yang dilakukan oleh orang tua.

Kedua, Kecerdasan emosi adalah kemampuan mengenali emosi diri sendiri dan orang lain, kemampuan memotivasi diri sendiri, dan kemampuan mengelola emosi dengan baik pada diri sendiri maupun dalam hubungan dengan orang lain agar perilaku anak sesuai dengan standar yang ada di lingkungannya.

Ketiga, lingkungan yang ada disekitar anak akan memberikan pengalaman yang membentuk perilaku anak. Pengalaman anak dari lingkungan akan menjadi patokan dalam bertindak dan berkata. Apabila yang anak dapat adalah contoh yang baik maka akan baik perilaku anak, namun apabila contoh yang didapat anak adalah perilaku buruk maka akan buruk perilaku anak. contoh lingkungan adalah keluarga, masyarakat dan teman sebaya.

Keempat, Kemampuan orang tua dalam membingan anak karena moral dan anak tidak dilahirkan secara bersamaan, namun tumbuh dan berkembang dalam lingkungan dan pengawasan orang tua serta pendidik. Sehingga apa yang dilakukan oleh anak adalah gambaran apa yang didapat dari orang tua yang mendidik

\section{KESIMPULAN}

Berdasarkan hasil dan pembahasan penelitian yang telah dikemukakan pada bab sebelumnya dapat disimpukan bahwa uji korelasi sederhana antara mindful parenting terhadap perilaku moral siswa serta bimbingan orang tua terhadap perilaku moral mempunyai hasil yang sama yakni 0,000 , yang berarti bahwa ada hubungan yang signifikan. Hasil uji korelasi berganda antara mindful parenting dan bimbingan orang tua terhadap perilaku moral siswa 0,000 sehingga dapat disimpulkan bahwa terdapat hubungan yang signifikan antara mindful parenting dan bimbingan orang tua terhadap perilaku moral siswa. Nilai $\mathrm{R}$ Square sebesar 0,145 sehingga dapat disimpulkan bahwa mindful parenting dan bimbingan orang tua berpengaruh sebesar $14,5 \%$ sedangkan $85,5 \%$ dipengaruhi oleh variabel yang lain.

\section{DAFTAR PUSTAKA}

Aji, M. Q. W. A. (2018) Tugas Dan Peran Guru Tak Tergantikan Oleh Teknologi, Kompas.Com. Available At: Https://Mediaindonesia.Com/Read/Detail/191929-Tugas-Dan-Peran-Guru-Tak-Tergantikan-OlehTeknologi.

Alfianti, Y. F. (2018) Hubungan Mindfull Parenting Dengan Stress Pengasuhan Ibu Yang Memiliki Anak Retardasi Mental Di Sekolah Luar Biasa (Slb-C) Tpa Kabupaten Jember. Universitas Jember.

Awang, K. A. S. (2015) Pola Asuh Orang Tua Dalam Bimbingan Moral Anak Usia Prasekolah, Universitas Islam Negeri Sunan Kalijaga. Universitas Islam Negeri Sunan Kalijaga.

Berns, R. M. (2010) Child, Family, Shool Community: Socialization And Support. Edited By C. Shott. Belmont: Wadsworth Cengage Learning.

Duncan, L. G., Coatsworth, J. D. And Greenberg, M. T. (2009) 'A Model Of Mindful Parenting: Implications For Parent-Child Relationships And Prevention Research', Clinical Child And Family Psychology 
315 Hubungan antara Mindful Parenting dan Bimbingan Orang Tua Terhadap Perilaku Moral Siswa Sekolah Dasar Selama Pembelajaran Daring - Zainul Arifin, Yulia Eka Yanti

DOI: https://doi.org/10.31004/edukatif.v4i1.1423

Review, 12(3), Pp. 255-270. Doi: 10.1007/S10567-009-0046-3.

Fitri, M. And Na'Imah (2020) 'Faktor Yang Mempengaruhi Perkembangan Moral Pada Anak Usia Dini', $A l$ Athfaal: Jurnal Ilmiah Pendidikan Anak Usia Dini, 3(1), Pp. 1-15.

Habsoh, S. (2021) 'Pelaksanaan Bimbingan Belajar Oleh Orang Tua Dalam Perkembangan Moral Spiritual Anak Di Raudhatul Athfal', Jurnal El-Audi, 1(1), Pp. 20-36.

Herminingsih, Y. K. (2013) 'Hubungan Penerimaan Diri Dengan Penalaran Moral Pada Penghuni Lembaga Pemasyarakatan Anak Di Blitar', Jurnal Psikologi Tabularasa, 8(2), Pp. 717-723.

Julkifli, M. (2019) 'Strategi Guru Mengelola Kelas Dalam Anak Lamban Belajar (Studi Kasus Di Sdit AlFirdaus Banjarmasin)', Tesis, Pp. 1-170.

Lagiana, T. (2017) Pengaruh Bimbingan Orang Tua Dan Pola Asuh Orang Tua Terhadap Perilaku Belajar Siswa Kelas Iv Dan V Di Sd Negeri 2 Grogol Sawoo Ponorogo Tahun Ajaran 2016/2017, Institut Agama Islam Negeri. Institut Agama Islam Negeri.

Nuraini, F. And Mahmud, T. A. (2020) 'Peran Orang Tua Dalam Membentuk Karakter Anak Di Era Globalisasi Di Desa Masigit Kelurahan Citangkil Kota Cilegon', Jurnal Pendidikan Pancasila Dan Kewarganegaraan, 3(2), Pp. 103-114.

Nurmalitasari, F. (2015) 'Perkembangan Sosial Emosi Pada Anak Usia Prasekolah', Buletin Psikologi, 23(2), P. 103. Doi: 10.22146/Bpsi.10567.

Risdiany, H. And Lestari, T. (2021) 'Edukatif : Jurnal Ilmu Pendidikan Pengaruh Film Kartun Upin Dan Ipin Terhadap Perkembangan Moral Anak', 3(4), Pp. 1366-1372.

Sofyan, I. (2019) 'Mindful Parenting: Strategi Membangun Pengasuhan Positif Dalam Keluarga', Journal Of Early Childhood Care And Education, 1(2), P. 41. Doi: 10.26555/Jecce.V1i2.241.

Yunitasari, R. And Hanifah, U. (2020) 'Pengaruh Pembelajaran Daring Terhadap Minat Belajar Siswa Pada Masa Covid 19', Edukatif: Jurnal Ilmu Pendidikan, 2(3), Pp. 232-243. Doi: 10.31004/Edukatif.V2i3.142. 